\title{
The Development Strategy of Financial Management in Modern Enterprise in the Era of "Internet Plus"
}

\author{
Jingyu Wang \\ Nanyang Institute of Technology \\ Nanyang, Henan 473004, China
}

\begin{abstract}
The application of the "Internet Plus" concept in the traditional enterprise field is essentially the integration of traditional industry and Internet industry, which inevitably changes the production mode, operation mode and business form of the traditional enterprise. The requirements for various functional departments of the enterprise also change accordingly. Recently, there is growing debates on how financial department bears the brunt of the "Internet plus" industry integration, as it's one of the core departments in the enterprise organization. In this paper, we analyze the current situation of financial management of China's traditional enterprise and clarify the necessity of financial management innovation under the background of industrial integration. On this basis, this paper raises suggestions on innovative countermeasures for corporate financial management to help enterprises to cope with the operating environment under the background of "Internet plus".
\end{abstract}

Keywords-Internet plus; Enterprise; Financial management

\section{INTRODUCTION}

In recent years, with the continuous development of the national economy and the rapid advancement of science and technology, computer technology and network communication technology have begun to enter the public's vision, and have even become one of the most important tools in China's production and life. Traditional industries, including the financial, educational, and trade industries and the Internet are embarking on an unprecedented journey of integration. "Internet plus" has become a new economic form of modern society. Under the new "Internet Plus" economic model, in order to adapt to the development of the times and seize development opportunities, enterprises must actively reform their business management concepts and promote the transformation of management and management methods. As a key component of enterprise management, financial management must also actively respond to the developmental needs of enterprises, comprehensively use Internet technology, and innovate financial management models to enhance the core strengths and market competitiveness of enterprises.

\section{CHARACTERISTICS OF THE NEW ECONOMIC FORM OF "INTERNET PLUS"}

\section{A. The basic concept of "Internet Plus"}

The concept of "Internet Plus" was first proposed in China at the Yiguan Mobile Internet Expo held in 2012. It mainly refers to the integration of various traditional industries and Internet technologies, including finance, transportation, education, media and market trade. "Internet Plus" is not a simple addition of the Internet to a traditional industry, nor is it a technological transformation of the traditional industry, but a new type of industry that has been produced through deep interaction and integration [1]. Currently, "Internet Plus" industry mainly includes Internet finance, Internet education, ecommerce, etc. Among them, "Internet Plus Finance" is represented by $\mathrm{P} 2 \mathrm{P}$ credit platform and third-party payment. It can be seen that "Internet Plus" has become a contemporary new type of economy, which has important impact on the market economy and business operations.

\section{B. Main features of "Internet Plus"}

The characteristics of the "Internet Plus" new economic form include:

First, information transparency. Internet technology enables real-time updates of information and extensive information sharing. Based on the Internet platform, both parties engaged in commodity trading or business cooperation can obtain relevant information at the same time, and the information is highly symmetrical. Both sides also have the same right to speak and have the right to express their opinions. Second, the economy is platformized. Industrial platformization is the main form of China's Internet economy in recent years. It is also an important development trend, such as Baidu, JD.com and Didi. Third, information digitization. Technologies such as cloud computing, big data, and the Internet of Things have realized the digital development of information, providing data support for corporate decision-making and changing traditional consumption methods. Analysis of the status quo of enterprise financial management and the necessity of innovation 


\section{ANALYSIS OF THE CURRENT SITUATION OF ENTERPRISE FINANCIAL MANAGEMENT}

In fact, before the Internet era has arrived, the financial management department is at the core of the enterprise, but due to restrictions in the traditional industry, corporate financial management activities do not maximize functionality.

Under the traditional industrial form, the production, operation and development of enterprises mainly depend on market channels. The correlation between market economy entities is small, the amount of information production and demand is small, and the speed of transmission is also limited by technology. In this case, corporate financial management mainly serves internal compensation and external marketing. In terms of department construction, only a small amount of financial personnel is sufficient. However, with the continuous improvement of the market economic system, the market competition is becoming more and more fierce, and the survival of enterprises depends more and more on the market itself.

Since the 1990s, the Internet has gradually become an important way for enterprises to open up markets and tap customers. At the same time, under the opportunity of enterprise information construction, enterprise financial management has also realized computerized transformation and began to use computer technology to process financial data. On this basis, the corporate finance department has proposed the requirement to expand the scale, including not only the increase in the number of financial personnel, but also the requirements for hardware resources, software resources, and information resources. In the process of financial management working with accounting software as the core, the division of financial management has become an inevitable requirement. At the same time, China has also established a modern accounting computerization mechanism in the enterprise administrative management level. Under the dual influence of internal and external factors, the corporate financial management must make a change.

Combined with the practice in recent years, the financial management innovation of enterprises has played an active role in business management, however there are problems as well. The following analysis is combined with the status quo [2].

The pace of informationization lags behind the speed of industrial integration. The development of the "Internet Plus" concept is in full swing, and the industry with industry integration as the development direction is increasing, which has created an illusion of "informatization flooding". In theory, the concept of "Internet Plus" can be applied to all traditional industries, but due to the lack of effective policy guidance and market mechanisms, there are not many industries that can achieve better integration and achieve market benefits, and most of them are Internet oligarchy. Monopoly, for example, Alibaba Group includes e-commerce platform, Internet finance, music industry, tourism industry, booking system, etc. These industries have inherent advantages that are easier to integrate with the Internet. For the majority of small and medium-sized enterprises, the development of enterprise informationization is mainly to achieve the savings of operating costs, and its advantages are difficult to transition to the financial management level, and the speed of financial management information is obviously lagging behind. A large part of the financial management information construction of enterprises is based on the "convenience" of enterprise information construction, and only the initial stage of investment. In practice, financial management has been transformed from manual operation to computer operation, which is used to save labor costs and time costs. However, it has not changed in essence. The financial management of enterprises is still excluded from the enterprise management decision-making system. The financial data provided is mainly the breakdown of income and expenditure is not enough to support the needs of industrial integration. For example, some companies are involved in the "Internet Plus" field, and the production and operation behaviors are constantly integrated with the Internet industry (such as e-commerce marketing), but financial management only meets the simple computerized system, artificially excluding Internet elements.

Lack of comprehensive ability enterprise financial management talents. In the context of the "Internet Plus" industry integration, Internet applications are the most basic financial management capabilities. A well-functioning information-based financial management system can not only be used for accounting work, but also involves material management, production management, technology management, equipment management, market management and so on. From a technical point of view, it is not difficult to establish such a financial management system. However, to fully utilize the functions of the system, it is necessary to have financial management talents with multiple capabilities at the same time. On the one hand, it is essential to understand the internal situation of the enterprise and maximize the data services provided by each department. Also, it is necessary to fully understand the market, grasp the key points of market economy of industrial integration, and have the ability to discover problems, analyze problems and solve problems from a macro perspective, and provide reasonable suggestions to the decision-making level of enterprises in a timely manner. However, in reality, most enterprises lack talents with comprehensive ability and quality, and they will face the obstacles of communication and increased labor costs from the perspective of professionalism. If the "innovation" capability is included in the talent demand element, the talent gap will be even greater.

The effectiveness of corporate financial information management is poor. There are two main types of information provided by traditional enterprise financial management. One is the data used for production and operation, and the other is the data on the profit of marketing. In addition, there is a small amount of market price and manpower, information such as cost. In the context of "industry integration", information is an essential factor for enterprises to make decisions, especially financial management information, which involves the current business status of enterprises and the key elements of future development. The traditional financial management model lacks the ability to sort, analyze and screen information, and the imperfect financial management mechanism can easily lead to the lack of decision-making basis in the process of strategy formulation. Correspondingly, the Internet economic factors 
are changing rapidly, and financial information management Poor effectiveness will inevitably lead to the development of enterprises.

\section{THE NECESSITY OF ENTERPRISE FINANCIAL MANAGEMENT INNOVATION}

\section{A. The necessity based on network technology}

Under the background of "Internet Plus" industry integration, the proportion of Internet functions has been improved, and corporate behavior has gradually shifted to the Internet. For example, in marketing, the network platform can completely replace the traditional market channels. As an important part of the daily operation of the enterprise, financial management is also based on the connection between Internet technology and other departments. At the same time, the core of the financial management informationization process is financial software. The traditional accounting management model has not adapted to modern financial management requirements, so it must be based on the enterprise's own needs are innovated, and the financial management of the enterprise is centralized, thus meeting the financial management needs of the Internet era [3].

\section{B. The necessity based on business development}

Enterprises under the "Internet Plus" concept to transform, the prerequisite for industrial integration is to absorb the various advantages of the Internet, in order to improve the market competitiveness of enterprises and improve market coverage. Obviously, Internet finance is one of the advantages. Compared with traditional finance, it has the advantages of low cost, high efficiency and fast speed. The biggest feature of the enterprise under the concept of "Internet Plus" is the realization of network platform operation. For example, network orders, network remittances, etc., the financial management activities of enterprises have not only connected with the production factors of enterprise production factors, but directly connected to the market through the Internet, and financial information has also evolved from static data to dynamic data. In order to meet this business need, financial management innovation is imperative, and its innovation directly affects the ability to control complex financial data.

\section{The necessity based on financial security}

The financial security of traditional enterprises mainly refers to the balance of payments and financial funds. In the Internet economy system, the scope of corporate financial security is extended to all financial related data. Based on the enterprise financial system, it will carry out innovations for corporate financial management, including information leakage prevention, management personnel quality, hardware equipment protection, and computer virus infringement.

\section{INNOVATION COUNTERMEASURES FOR ENTERPRISE FINANCIAL MANAGEMENT UNDER THE BACKGROUND OF "INTERNET PLUS" INDUSTRY INTEGRATION}

\section{A. Innovate financial management system}

Under the new form of "Internet Plus", enterprises must innovate the way of building financial management systems, and rationally organize the organization of financial management according to the characteristics of the "Internet Plus" era and the actual needs of corporate financial management. Also, enterprises need to improve the financial budget system and fully recognize the importance of financial budgeting for corporate financial management in the new environment. What's more, it's better to implement financial management responsibilities, clarify organizational responsibility and execution responsibilities for financial budget work. Determine the work content of each post and conduct comprehensive information collection and collation. And establish a supporting evaluation and evaluation system to ensure the effective implementation of corporate financial management responsibilities. Under the complete system guarantee, promote the standardized development of corporate financial management, and ensure that the financial budget work is carried out in an orderly manner [4].

\section{B. Actively build a big data financial management platform}

In the context of "Internet Plus", enterprises should completely change the closed financial management mode, actively build a big data financial management platform, apply the "Internet Plus" thinking, highly integrate financial management information data, and give full play to the advantages of the Internet, and apply it. Cutting-edge technologies such as data and cloud computing improve the efficiency of information data acquisition. Timely update and real-time monitoring of financial information data of enterprises to ensure the timeliness and authenticity of financial information data. Appropriately adjust the financial staff's configuration structure, and put more manpower into the financial analysis work, thus improving the financial management level of the enterprise. At the same time, comprehensive use of digital signature technology, encryption technology, intrusion detection technology, etc., improve network security protection capabilities, give full play to the positive role of the Internet financial management platform. 


\section{Optimize the financial management workflow}

Under the "Internet Plus" era, the enterprise financial management model has undergone profound changes. The following aspects should be taken to optimize the financial management workflow: (1) Integrating accounting technology and information technology, and taking online office and mobile office as modern enterprise financial management. The main way of doing work. With the large coverage of electronic money, online payment services have gradually matured, and accounting settlement should gradually develop toward online settlement; (2) Under the paperless office mode, the data transmission method of financial management has undergone profound changes, and the original financial data Collect and organize directly from the network, store it in the network, implement traditional accounting operations in the network system, and the financial credentials become accounting vouchers processed by the financial management software; (3) Network development of accounting business and Network security deployment is carried out simultaneously. According to the importance of financial information, different levels of network security protection technologies are used to protect financial information data, and network security protection is used as the basis for the development of Internet accounting services. (4) Traditional management mode centralized management mode change, through the establishment of a unified settlement center, to ensure the financial monitoring of the subordinate structure of the business entity, thereby ensuring the quality of financial accounting.

\section{Strengthen the training of compound financial management talents}

Under the background of "Internet Plus", enterprises actively introduce technology and equipment, and innovate financial management methods, while strengthening the cultivation of compound financial management talents, so that they have the financial management ability under the "Internet Plus" model. Traditional financial management methods have been difficult to adapt to the actual needs of financial management at this stage. Therefore, financial managers work must be updated, e.g., to make financial management personnel proficient in the functions of financial management software system, and to use software application as the basis for financial management work. Financial personnel to carry out financial statement management, accounting and auditing, and financial auditing must be carried out through the Internet, thereby improving the timeliness of financial management and financial management efficiency. In response to these aspects of financial management needs, companies should actively recruit composite financial management personnel with financial management capabilities and network office capabilities. At the same time, it's advised to actively carry out internal training work, establish a long-term training mechanism, and strengthen the professional skills of financial personnel, introduce the "Internet Plus" thinking and network office related skills, and improve the comprehensive ability of corporate financial personnel. Give full play to the main role of financial management personnel, and gradually become the leading force to promote corporate financial management reform.

\section{CONCLUSION}

In summary, in the era of "Internet Plus", the content and mode of enterprise's financial management have undergone profound changes. Fully considering the impact of the "Internet Plus" background on corporate financial management, and actively carrying out financial management innovation, can help Enterprises improve their financial management. Also, making full use of the "Internet Plus" background for the opportunity and technical support brought by the financial management reform of enterprises can promote the efficient development of financial management of enterprises and achieve integration with the international convention.

\section{REFERENCES}

[1] X. Luo. Research and Exploration on the Training Mode of Financial Management Professionals in Higher Vocational Education under the New Internet Economy [J]. Chinese and Foreign Entrepreneurs 2017 (06).

[2] H.L. Ma. Discussion on the Financial Management Mode of Enterprises under "Internet Plus" [J]. Tax Economic Research 2015 (6).

[3] B. Wang. "Internet Plus" Background of Financial Management of Transportation Enterprises [J]. Administrative Assets and Finance, 2016, (24): 82-83.

[4] M. Zhang. Research on the innovation of SME management mode under the background of Internet Plus [J]. Modern Business, 2016 (35). 